821.163.41.09-2 Поповић А. https://doi.org/10.18485/kij.2019.66.1.3

ЗЛАТКО М. ГРУШАНОВИЋ

Завод за унапређивање образовања и васпитања
Оригинални научни рад

Примљен: 19. 03. 2019.

Прихваћен: 24. 04. 2019.

\title{
ТИПОВИ ХЕРОЈА У СРПСКОЈ ДРАМИ ОД 1990. ДО 1994: АЛЕКСАНДАР ПОПОВИЋ - БЕЛА КАФА
}

\begin{abstract}
Полазиште за истраживање у овом раду јесте корелација турбулентних друштвених кретања током деведесетих година 20. века и драмског стваралаштва у тој деценији, на примеру драме Бела кафа Александра Поповића, која је извршила утицај постављањем на сцену. Истраживање је усмерено на утврђивање подударности у изградњи и разумевању хероја као драмског протагонисте и хероја као друштвеног феномена. Да би се утврдио концепт хероја као књижевног и као друштвеног конструкта у раду је најпре дат осврт на културолошки и социолошки контекст. Тиме је осветљена чињеница да су оба типа хероја скоро увек пројекција друштвеног идеала, система вредности или друштвене потребе, односно да како су се кроз историју и књижевне епохе истовремено мењали друштвени идеали и типови хероја и сваки период у развоју друштва изнедрио је одговарајућу врсту хероја. Како су књижевни хероји често, али не и обавезно, оличавали друштвене хероје у свету уметности, онда се испоставља да је доминантна тема овог рада управо однос друштвене стварности и уметности сагледане кроз концепт херојства.
\end{abstract}

Кључне речи: драмски херој, драма, трагички херој, антихерој, исмејани херој, гротеска, иронија, сатира, хумор, мелодрама, трагичка радња, комичка радња.

При изучавању типова хероја у српској драми у првој половини деведесетих година прошлог века, полази се од концепта хероја као социолошке категорије и од тога да су овакви модели директно условљени историјским тренутком у коме настају. Пошто хероји, нарочито у кризним и ратним временима, задобијају различите вредности у зависности од друштвеног контекста, циљ је, између осталог, да се испита зашто је позориште на почетку деведесетих активно учествовало у трагању за идентитетом, стварајући хероје блиске пожељном друштвеном моделу, да би се после неколико година концепт херојства урушио у своју супротност. Такође, интересантно је увидети и начин на који се у српској драматургији

*grusanovic@gmail.com 
епски традиционални херој трансформисао у проблематичног хероја, отуђеног од света и у потрази за идентитетом.

Потреба за херојима је општељудска потреба, која се нарочито јавља у временима оштрих сукоба добра и зла, када једна моћна сила негативно делује на нешто што се колективно перципира као добро. Године које истражујемо су са становишта тадашње званичне политике и дела јавности доживљаване као митско време, у коме је српски народ на страни добра и представља жртву, док су други посматрани као агресори и антихероји. Писци су трагали за правом формом историјске истине, било кроз реалистичне комаде било кроз алегорије о савременом добу. За то су имали разлоге уметничке, али и друштвене, политичке, националне или пропагандне природе, на шта упућује и Марта Фрајнд: „За драму која се бави историјом подједнако су значајне историја као слика прошлости и историја као садашњост чији се проблеми рефлектују на неки догађај у прошлости. [...] Зато термин 'историјска драма' неизбежно обухвата и историју као 'јуче' и историју као 'данас'. То опет има дејство слично деловању предања, легенди и политичких теорија на суштину овог драмског жанра" (Фрајнд 1996: 18).

Крајем деведесетих, друштвене околности изнедриле су тип хероја - ослободиоца, избавитеља који се бори да сачува целокупан српски народ од неправедне агресије. Такав херој имао је особине митских вођа, јасно кореспондирајући са косовским јунацима. Обнављање националних митова у српском позоришту имало је своје узроке, које Мило Ломпар види у „самопорицању” националности у прошлости зарад идеје југословенске нације. Југословенство је за Хрвате било „интегративна сила, док је на Србе деловала дезинтегративно [...] Тако су Срби били подложни нестајању у Југославији, док су Хрвати припадали супротном процесу: настајању кроз Југославију” (Ломпар 2014: 332).

Са распадом СФРЈ нестао је и вредносни систем који је она заступала, па је упражњени простор испуњен личностима које су у социјалистичком систему биле негативни јунаци, такорећи табуиране личности. Народ је, у потрази за идентитетом, имао природну потребу за узорима, али упоредо са националном рехабилитацијом дошло је и до инструментализације мита и хероја. Тако се „самопорицање” трансформише у прецењивање, јер „не може, међутим, ниједан национализам, па ни онај који је био на сцени 'последњих двадесетак и више година', бити део духа самопорицања него њему супротног духа самопрецењивања” (Ломпар 2014: 493). Процес „самопрецењивања” сопствених нација одвијао се код свих учесника у политичкој кризи бивше Југославије.

Драмско обликовање националне идеологије било је нарочито заступљено. Националне идеје, те покушаји разумевања и тумачења друштвених и политичких прилика крајем осамдесетих и почетком деведесетих година, дали су подстицај за низ драма које су у прошлости нације тражиле одговоре на савремена збивања. Такве драме настајале су и због пробуђеног интересовања публике и целокупног друштва за националну историју, па су стога писци покушавали да уметнички обликују политичке и друштвене идеје тог времена. 


\section{Александар Поповић - Бела кафа}

За ово истраживање значајна је драма Бела кафа Александра Поповића. Први пут је приказана на малој сцени Српског народног позоришта у Новом Саду 1990. године (режија Бранко Плеша), а комад је био изузетно актуелан, јер је писац наводио публику на суочавање са прошлошћу и прихватање грешака. Поповић је покушао да прикаже страдање и заблуде нашег народа током неколико не тако давних деценија, у којима је дошло до пораза југословенске војске, прогона српског народа, грађанског рата у оквиру Другог светског рата, Голог отока, партијске „чистке”. Бела кафа је прича о генерацијском сукобу и расулу породице у историјском хаосу, али и прича о опстајању у таквом времену, и то углавном захваљујући аморалним компромисима. Поповић је истраживао последице великих друштвених промена, потреса и превирања, пратећи судбину једне нетипичне српске породице. У колективну трагичну драму уткане су појединачне судбине и компликована социјално-политичка ситуација.

Кроз судбину једне породице Поповић у овој драми покушава да прикаже историјске прилике у распону од 1940. до 1960. године, и то: распад Краљевине СХC, комунистички покрет, рат, ослобођење, Информбиро, послератни комунизам.

У драми се појављује шест ликова: Момчило Јабучило, Мајка Јања, Дели Јова, Црква Ружица, Срђа Злопоглеђа, Зора Шишарка. Сви они су изграђени као представници различитих политичких идеја, страсти, па и патолошких стања. Контрастне карактеристике ликова стварају предуслове за драмски сукоб. Сви имају прошлост у којој нешто крију и која оптерећује и утиче на будућност, и сви су помало дволични, што је нарочито уочљиво у другом делу драме, где је приказан послератни социјализам, у коме је дволичност често спасавала људе од проблема у новоствореној држави. Нико није слободан у таквом свету, сви су усамљени и уплашени. И Срђа и Момчило су идеолошки ангажовани, само што су им идеологије супротних предзнака. „Идеологија је систематизовани скуп политичких идеја, принципа и друштвених идеала који репрезентују поглед на свет неке друштвене групације изражавајући њене интересе и потребе, створен у практичне сврхе подстицања те групације на политичко деловање, у форми идејне потпоре активностима на плану освајања или очувања политичке власти или, пак, утицаја на њу” (Симеуновић 2009: 116). Срђина комунистичка идеологија и Момчилов национализам трајно су непомирљиви и разорно делују на њихове животе, кроз које, као и кроз животе других ликова, ишчитавамо девијантну слику друштва. Момчило не види да долази нова идеологија, у свему супротна његовом епском, јуначком српству, али опажа, попут јунака Ковачевићеве драме Ђенерал Милан Недић, да ће то ново доба бити узрок многих невоља будућим нараштајима. Срђа на крају схвата колико друштвена стварност одступа од идеала комунизма. Мајка Јања не види ништа осим деце, а Зора ништа осим властите сексуалности. Једино Јова наслућује реалне обрисе света, али ништа у њему не може да промени, осим себе самог: иако је у бити хтео да буде као Срђа, живот и 
Момчило натерали су Јову да мења стране како би преживео, па је он пре свега антихерој.

Као и у драми Мрешћење шарана, Поповић је и овде извео на сцену сличне јунаке, који су живели по опортунистичком обрасцу, мењајући се према захтевима новог времена и својих позиција у њему. Као такви, Поповићеви драмски ликови живе у мрачној стварности, без слободе, уз одсуство љубави и моралних вредности.

Момчило је лик немоћан да промени ситуацију, а његова немоћ је пропорционална Срђиној моћи. Ипак, Момчилу је преостао ауторитет „главе породице”, који до краја драме није поништен, док је Срђин ауторитет вештачки, конструисан у погодном политичком тренутку, па зато на крају драме, када се друштвене околности промене, он лако остаје без свега.

Момчилова моћ лежи у издржљивости, искуству и патријархалној традицији. Он о свему и свима зна све, анализира и увиђа грешке своје породице, грешке свог народа и грешке новог система, предвиђајући их до данашњег времена. Ниједан од њих двојице не црпи моћ из сопствених квалитета, већ из функције коју обавља у одређеном друштвеном контексту. Писац покушава да кроз критику комуниста као кратковидих демагога успостави повратак предратним вредностима.

Момчило и Срђа представљају заправо лице и наличје једног друштва. Тако је Срђа, дојучерашњи херој комунистичког доба, у Поповићевој драми лик који поприма све одлике негативног хероја. Модел херојства код оба јунака, Срђе и Момчила, није затворен, он је у непрестаном развоју. Срђа је лик који би требало да се приближи традиционалном хероју, али се до краја драме заправо развија у антихероја. Разлог за то је пре свега слепа мржња према буржоазији и Момчилу, који је у исто време био и његов доброчинитељ и могући кривац за несрећу његове породице. У претходном, социјалистичком обрасцу, Момчило је, као буржуј, заузимао позицију негативног јунака, али у Поповићевој драми постаје трагичан лик, представник свих оних послератних осуђеника који оличавају непријатеље социјализма. Пре почетка рата, њих двојица су имали замењене улоге у друштвеном поретку. Концепт њиховог херојства/антихеројства у ствари је сукоб два морала, два тумачења историје: послератног и савременог, у коме се друштвена перцепција променила. Из угла победника рата, комунистичких идеолога, Момчило је антихерој, издајник.

Момчило носи надимак Јабучило, због чега је алузија на војводу Момчила, праведног и великог јунака на кога се угледао Марко Краљевић, а који је имао летећег коња Јабучила, још јаснија у намери да му се додели митски идентитет, али уједно указује и на промену његове позиције. Премда је национализам у новом систему потискиван, а националисти као антихероји затварани или осуђивани, Поповић успоставља равнотежу, приказујући Момчила као позитивног јунака, који не страда својом кривицом, већ је жртва промена у друштвеном систему. Он је глава породице и фабрикант који је својим радом у првом облику капитализма успео да се обогати и изгради фабрику. Он је представник пред- 
ратне буржоаске класе, одрастао на грађанској традицији. Иако је у прошлости чинио неке неморалне ствари, што сазнајемо из Срђиних оптужби, у драми он представља моралног резонера, тип искусног мудраца кога нико не чује. Он је прошао развојну линију од моћи коју је имао у прошлости, до тога да на крају живи од милостиње своје деце. Момчилову предисторију антихеројства и буржоаског начина живота сазнајемо кроз интегрисану експозицију, посредно из коментара ликова, због чега су те информације субјективне и непоуздане. Од почетка рата до ослобођења, Момчило је искључиво трагички херој - његова упорност, презир према новом друштвеном поретку и непоколебљиво преживљавање недаћа, односно покора и испаштање, јесу врста херојског отпора. Премда је у драми приказано ратно и послератно време, Поповић се посредно обрачунава са комунистичком идеологијом, која је гушила слободну свест појединаца, али и развој националне свести. Он је препознао и подржао нови идеолошки преврат у друштву: негативни предзнак се појавио испред свих идеолошких одредница. Ликови резонера које одликују набујали национални понос и љубав деведесетих година постају хероји, док дојучерашњи хероји, победници, попут Срђе, представљају антихероје и узрок каснијих ратова који су уништили земљу.

Срђа и Момчило су сличног темперамента и карактера, али супротних убеђења, те је зато њихов сукоб неразрешив. Они не признају страх и грешке, тешко показују наклоност и саосећање. Ипак, Момчило није тип бескрупулозног буржоаског зеленаша, каквог је комунистичка пропаганда неговала у литератури. Он је човек који воли свој народ: „Хоћу и ја да наздравим свима онима који мрзе нас Србе” (Поповић 2001: I, 1).

Он је тип традиционалног српског националисте, представник оног великог дела међуратног грађанства које није разумело и прихватило идеју Југославије. Његова скепса је нашла упориште у историјској реалности, што показује и ова Момчилова реплика: „Па нама Србима у Хрватској се већ спрема покољ, јавио је радио. [...] То ли значи смера Коминтерна у спрегу са Хитлером и Ватиканом, да побије све Србе, па да после нашу груду преплави Кинезима. [...] Није он мени од данас ништа, а и ти испред имена да бришеш оно 'дели', ниси ти делија, то може само прави Србин да буде" (Поповић 2001: I, 2).

Момчило је у сукобу са наизглед уређеним светом. Он не прихвата нову идеологију и покушава да живи онако како мисли да треба да би се сачувала част, не заборављајући свој народ и традицију. Усамљен и пасиван, он чезне за белом кафом, симболом друштва које је нестало. Он схвата да је стварност другачија од снова и жеља, што је заправо нека врста критике и његовог и новог комунистичког доба, али се не мења. Премда је у младости веровао да ће у животу бити све како је замислио, па се „ко лав борио”, Момчило на крају спознаје да је сада све то бесмислено: „Схватио сам да у животу иде све својим природним током мимо наших снова" (Поповић 2001: I, 2).

Дубина Момчиловог лика огледа се пре свега у сукобу прошлог живота са садашњим тренутком, а притисак друштвеног контекста на њега повећава се током радње, остављајући га на крају драме на сметлишту, сиромашног, али и 
даље истих размишљања и осећања. После рата, Момчило је лишен имовине, достојанства, породице, части, здравља и живи од милостиње. Он је неко ко је волео свој народ и био умерени националиста, затим разочарани идеалиста, а на крају је постао и реалиста. У послератној Југославији Момчило постаје негативни јунак, експонент буржоаског друштва, али у време када се представа изводи, публика га перципира као јунака мученика, јер је близак савременом добу, у коме се поново јавља љубав према народу и прошлости. Истовремено, Поповић критички говори о социјалистичком друштву, чије се деловање претворило у пљачку без идеолошког значења. У таквим околностима, свака идеологија се на личном плану претвара у своју супротност, у алиби за лични обрачун. Ипак, писац показује више симпатије према Момчилу и његовим идејама него према Срђи, као да жели да поручи да се кроз историју не може ходати без свести о идентитету нације.

Споредни лик, Момчилов син Јова, у непрестаној је потрази за идентитетом, те му је надимак „дели” додељен у иронијском кључу, јер он мења стране у рату. Дели Јова је због свог опортунистичког става изопштен из друштва, неомиљен, али врло присутан антихерој у историји. У тешким временима било је мудро бити неопредељен, не приклонити се ником и сваком у исто време, али у реалности то није било нимало једноставно. Прво комуниста, потом дезертер, па припадник љотићевског покрета, Јова је симбол свих оних који у рату немају ниједну другу идеологију осим идеологије преживљавања. Иако је покушавао да буде попут Срђе, далеко је од његове страсти. Јова има само једну, обичну жељу да живи својим животом, али у томе не успева, јер да би преживео, мора да мења стране у рату. Смисао његовог трагања за идентитетом лежи у начину како преживљава. Након безуспешне потраге, Јова на крају постаје и опортуниста, који у послератним чисткама успева да заштити свој живот.

JOBA: Живот издајника је тежи од смрти, тато.

МОМЧИЛО: И поврх свега син ми је Љотићев официр.

JOBА: Вајан ли сам ја официр. Мастиљара. Чекај, нису ваљда и мене помињали. (Момчило скрушено клима главом) Јесу. Е видеће они који сам ја српски фашиста, само док ми од Срђе стигне шифрована порука. (Поповић 2001: III, 2)

Поповић, кроз Јовин лик, намеће мисао да у тешким временима не може бити неопредељених, тј. оних који се опортунистички опредељују за сваку страну. У таквом свету хаоса, мрака, ниједна идеологија није исправна, па чак ни потреба за простим преживљавањем. Ипак, такви ликови се боре да би преживели, макар и по цену својих идеја. Историја показује да, за разлику од хероја, који често умиру за своја убеђења, ликови попут Јове, без карактера и идеолошких уверења, углавном преживе тешке тренутке.

Актанцијални модели које ћемо установити могу нам помоћи да идентификујемо функције у сижејној структури комада. На општем плану, објекат свих ликова у актанцијалном моделу био би срећа, само што је различити ликови различито доживљавају. Срђа је види у победи и одржању комунизма, а Момчило у повратку прошлости, у којој је био срећнији. Актанцијални модели се не 
искључују узајамно. За нас је занимљив актанцијални модел Ружице, јер је она трагички херој који се жртвује зарад среће другог.

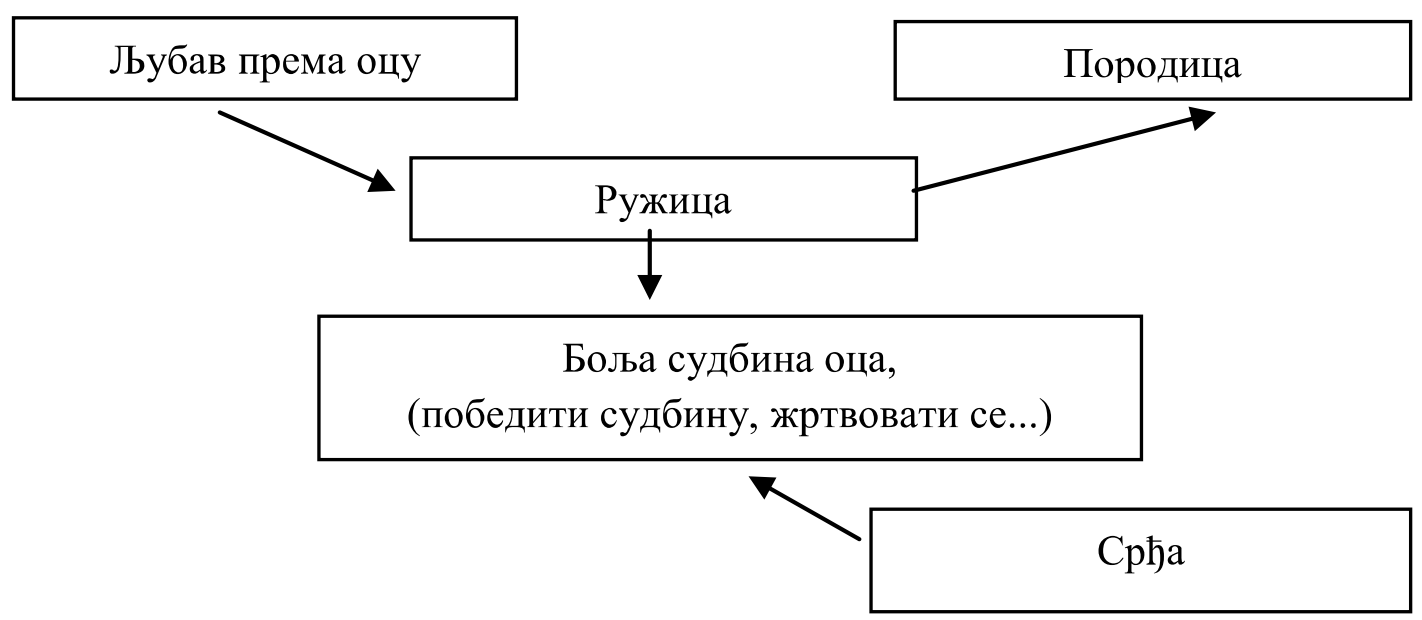

Ружица на свом путу нема помоћника, а противник јој је исти лик који може омогућити бољи живот за оца - Срђа. Срђа је, међутим, истовремено и лик због кога њен отац пати. Измирењем са главним кривцем за очеву судбину и ступањем у брак са њим, Ружица ће оца избавити из затвора, он више неће бити гоњен, а породица ће бити спасена. Њен унутрашњи сукоб (проистекао из нерешеног амбивалентног односа) настаје у трпљењу таквог живота и утиче на поступке према супругу Срђи. Сукоб ова два лика јесте сукоб два различита друштвена модела: кћерке представника предратног грађанско-буржоаског сталежа, с једне, и представника новонасталог система, с друге стране. У новонасталој држави, грађанин као модел је све извесније нестајао, да би се деведесетих година опет почео јављати у неким драмама и романима као идеални тип хероја, jep се грађанин посматрао као прежитак буржоаског друштва, а самим тим опозиција актуелном поретку. Дакле, национализам није био једини одговор на распад СФРЈ, већ је постојао и покушај успостављања континуитета са грађанском традицијом која је такође имала свој доживљај нације.

Ружица је сложен лик: она радњу у исто време трпи, те има особине жртве, али и покреће, светећи се Срђи, који је узрок свих невоља, те има и особине бунтовника, осветника. Жртвовање је свакако једна од битних особина модела хероја и поткрепљује моралну супериорност. Ружица је тип побожне жене, која својом моралношћу одскаче од свих осталих ликова. Иако непривлачне спољашности, унутрашње врлине су јој благост, смиреност, праведност, истинољубивост, што су праве одлике хероја у тешком времену. Изгледом је сва незграпна и спљоштена, чега је и сама свесна: „Још да немам огледало па да ме лажете. (тишина) Без капи сам крви. Жута ко пувало. С три длаке на глави. То и није коса, то су мишји репови. А носина ми ко српски опанак.” Да би спасла оца, Ружица 
се покорава и удаје за Срђу, човека који је директно проузроковао многе недаће њеном оцу, па тим чином добија функцију хероја жртве.

РУЖИЦА: И ко ми то каже? Онај који је мога шлогираног оца пустио да се удружен са псом по ђубриштима повлачи. Онај који је мене са богом завадио. Онај који се зарад политике рођене мајке одрекао. Онај који рођену сестру презире и стиди је се. Онај би се сад изненада на спас душе позивао.

СРЂА: Што онда десет година живиш са мном у браку, ако сам оличење зла? (Поповић V: 1)

Ружицу прожима унутрашњи конфликт јер мора да потисне своју мржњу и живи са човеком кога не воли, те се отуда код Ружице може сагледати највећа промена - од хероја жртве до хероја бунтовника. Ипак, и она има потребу за љубављу, али се повлачи и прави емоционални отклон између себе и околине, што је последица њене идеализоване слике света. Она је од почетка драме у нескладу: радо би се мењала са Зором; жуди за љубављу, али није лепа, те страст потискује и усмерава према смерном начину живота и филозофији. Што је већи притисак друштвеног и конвенционалног, то је сложенији њен унутрашњи живот.

Ружичино херојство је на граници између доброчинства и жртвовања, а тиме подсећа на хероје хагиографија. У сукобу разума и осећања, код Ружице побеђује рационалност: она је до краја драме скромна и смирена, да би у последњем чину испољила осећање равнодушности и мржње према Срђи и свему лошем што он представља. Поповић је у овој драми заправо и истакао Ружицу као модел хероја.

Срђа је неко ко увек наступа са идеолошком мржњом према човеку који га је примио под кров, мотивисаном управо неразјашњеним околностима смрти оца. Срђа Злопоглеђа има карактеристичан надимак, јер га покреће искључиво нетрпељивост према свему што није у духу комунистичке идеологије. Поповић је Срђи доделио одлике негативног јунака, антихероја острашћеног новом идеологијом, која је важнија и од фамилије и од пријатеља. У корену његове идеолошке мржње заправо лежи уверење да је Момчило крив за смрт његовог оца.

СРЂА: Аха. Нада се да ће му Хитлер сачувати фабрику од нас.

МОМЧИЛО: Какав Хитлер. Која одбрана. Шта ви смерате са мојом фабриком? ликожа.

СРЂА: Смерамо да сва средства за производњу отмемо из руку експлоататора и гу-

МОМЧИЛО: То ли је, дакле, то. Ви наступате под паролом: Своје не дам, туђе дизам, то је српски комунизам. (Поповић 2001: II, 2)

На крају рата комунистичка партија изашла је као победник. „Легитимитет своје власти комунисти су нашли у митологизованој представи о НОБ-у која је сугерисала да је успостављен поредак природно израстао из прошлости" (Димић 2005: 82). Срђа због тога представља типичног традиционалног хероја, ослободиоца, модел хероја који жели да промени систем. Ипак, његов лик доживљава промену, па се пред крај драме претвара у модерног јунака, разочараног лика који схвата да је све време живео у илузији. У последњем чину почиње да воли, уместо да мрзи, тако да од једнодимензионалног типа фанатичног ко- 
мунисте добија и димензију разочараног комунисте. Срђа тек тада почиње потрагу за својим идентитетом, а писац нам приказује промену поимања херојства у систему вредности овог јунака. У време када је драма Бела кафа написана, за комунизам су се већ искључиво везивали негативни коментари и сматран је узроком пропасти једне државе. Оно што је у једном добу оличавало херојство у другом је предствљало антихеројство, те због тога време у Поповићевој драми пролази брзо, а писац, обухватајући период од неколико деценија, настоји да покаже проблематичност категоризације људи у бурним временима. Александар Поповић и у драмама попут Мрешћење шарана, Развојни пут Боре Шнајдера, Kyc петлић приказује ликове у измењеним историјским околностима и њихово колебање између тежње за непроменљивошћу и прихватања промена. Идеали хероја комунисте распали су се као и сама земља, па тако и Срђину промену на крају драме можемо посматрати као закаснелу спознају. Како Теофил Панчић примећује поводом новије поставке Беле кафе, у режији Милана Нешковића, „ову драму можемо читати као апендикс ранијих Поповићевих драма, нарочито драме Мрешћење шарана, или напросто једну од варијација, јер се креће у истом, готово опсесивном тематском и временском кругу и миљеу српске / београдске ситне грађанштине суочене са успоном али и наговештајем краја грандиозног социјалистичког пројекта који Поповићеви ликови читају на начин како би се могли окористити, у правцу задовољења најприземнијих нагона" (Панчић 2016).

СРЂА: Веровао сам у то без икакве сумње, исто као што сам касније веровао у остварење светске пролетерске револуције. (Тишина, мала пауза) Опрости ми.

РУЖИЦА: Шта да ти опростим?

СРЂА: Све. Молим те.

РУЖИЦА: Касно је сад.

СРЂА: Живот ми је разорен.

РУЖИЦА: Разорио си и ти мој.

СРЂА: Поражен сам.

РУЖИЦА: Поразила те твоја победа. Уосталом, сви смо поражени.

СРЂА: Ја сам комуниста, убићу се. (Поповић 2001: V, 1)

Овај кратак дијалог заправо је објашњење психолошке атмосфере у којој су се нашли комунисти деведесетих година. Дуг пут ка победи заправо је био пут ка поразу, а на том путу су поражени сви. Ружица не ликује нити осећа задовољство, јер схвата да нема победника.

Срђина сестра, Зора Шишарка, доследно је комични карактер у драми, а Мајка Јања својим уздржаним понашањем и трпљењем представља пасиван лик мученице, која херојски подноси сву тежину хаотичног доба, остајући доследна својим племенитим особинама. Ни у њеном лику нема контраста између унутрашњег и спољашњег начина живота, осим донекле у односу према Момчилу, где је могуће тражити неки скривен унутрашњи живот. Он се огледа у потиснутој љубави према Момчилу, индустријалцу који ју је спасао од сиромаштва, али је можда и крив за смрт њеног мужа. Упркос томе, она не показује мржњу према њему и његовој деци, управо супротно, блага је и помирљива, те покушава да 
оправда поступке свих укућана како би се у дом могао вратити мир. Зато је важна симболика „беле кафе”, кафе која никако да се попије, јер више нема некадашњег мира, више нема оне старе породице, нити грађанских вредности.

Да би приказао период од двадесет година, писац је морао да убрза време, па практично сваки чин обухвата период од неколико година. У другом чину, од окупације је прошло пет месеци, док су у трећем већ протекле три године. У четвртом чину је приказан крај рата, док пети приказује шездесете године послератне Југославије, гашење Голог отока и наступање либералнијег, „мекшег" социјализма. Иако је временски распон у драми неких двадесетак година, примарно место збивања се не мења - радња се одвија у Београду, а салон представља стециште свих ликова и исходиште свих расплета у драми.

Није случајно Поповић изабрао време почетка Другог светског рата, рата о којем се ни данас много тога не зна, а крије узроке многих каснијих проблема у земљи.

СРЂА: Ништа. Не иде ми тренутно како треба.

МОМЧИЛО: Кренуће. Па ће опет застати. Па ће опет кренути. Једни иду горе, други иду доле. Што је важило, престаје да важи.

СРЂА: Ти заборављаш да сам ја комуниста.

МОМЧИЛО: Море, био сам и ја некад радикал.

СРЂА: Није човек оно што једе.

МОМЧИЛО: Јер, крв је испред свега, да ње није, народима би се заједно с лањским снегом замео сваки траг.

СРЂА: Човек је оно што мисли.

МОМЧИЛО: Ма човек је оно што му је записано.

СРЂА: Мислиш, у карактеристици и партијској књижици.

МОМЧИЛО: Не, тикване, него у крви од искона. То је запис који се преноси с колена на колено, јер кост је од кости, и човек од човека, ко светлост од светлости. [...] Ви ћете на крају из похабане краљевске ложе пребројавати мртве у опустелој арени. Зато ми сад брзо реци: где данас теби зврји? (Поповић V: 1)

На крају драме Момчило „не зна ко је ко”. У последњој сцени појављује се шест различито обучених ликова, који припадају истом народу, али су преузели различите колективне идентитете; нема хероја ни антихероја, а Момчилова реплика постаје свеопште питање за све ликове и транспонује се на целокупан народ који после педесет година више не зна ни ко је, ни где је.

МОМЧИЛО: Ја припадам госпоштини, на народ рачунам једино као на радну снагу, ал' ви нас, брате, надмашисте у суровости. Питам се: је л' то неко од вас тражио да свој народ без велике потребе толико кињите и затирете све што је српско, за сто година да се не опорави од ваше ускогрудости. [...]

РУЖИЦА: Кад је већ крајње пропало, нек буде бар у пропасти весело. (Сви се брзо на сцени пресвлаче: Момчило у предратног капиталисту; фрак и халбцилиндер, мајка Јања у маоисткињу; Маова блуза и качкет са петокраком, Ружица као калуђерица; мантија и кукуљица, Срђа као партизански официр, Зора као секс бомба, а Јова као Љотићев официр; копоран, лаковане чизме и шајкача с кокардом - још док се облаче они говоре.)

JOBA: Па да оплетемо оно наше шумадијско: дрма ми се, дрма ми се на шубари цвеће.

МОМЧИЛО: Знам све шта имам, али не знам: ко сам. Уопште више не знам ко сам. (Сви ћуте, светло полако трне.)

А је л’ ви знате? (Поповић 2001: V, 3) 
Последњу реплику, Момчилово иронично питање, Александар Поповић упућује публици, и то из више разлога. Иако временска дистанца између тренутка у драми и тренутка њеног извођења није велика, довољна је да писац може да актуелизује политичке проблеме у садашњости, јер њихови узроци леже у прошлости. Његови ликови су изгубили идентитет, и то услед немогућности да се снађу у свим променама које су се десиле на нашим просторима током година описаних у драми. Управо у времену када се земља распала, а један идентитет дезинтегрисао, оставивши за собом више нејасних, проблематичних идентитета, писац поставља гледаоцима питање: да ли знају ко су они, тачније, да ли су после свега свесни свог идентитета.

Поповићеви ликови немају ширину (могућност избора), јер су детерминисани историјом и својим страстима које се појачавају до апсурда и трагикомичности. Момчило, богати капиталиста, једино може да гледа како његов капитал пропада у време рата и социјализма, сећајући се беле кафе и дивне прошлости. Јова не може да пружи оцу отпор и кроз целу драму покушава да буде на победничкој страни, али га ипак судбина пре свега исмејава.

Услед ширег временског распона у драми код Срђе и Ружице је најочигледнији развој лика, док су код осталих јунака промене незнатније. Особине свих ликова су интензивиране до гротеске, јер с огромном страшћу бране личне ставове, препуштајући се својој опсесији, без обзира на то да ли се ради о национализму, комунизму или сексуалној пожуди. Трагичност тих ликова и јесте у дезоријентисаности коју покушавају да превазиђу. Срђа се тако мења оног тренутка када комунизам постаје опасност по његов положај и живот. Страх и дилема који га изједају наводе га на покушај самоубиства. Ружица пролази пут од побожне девојке, преко калуђерице, до доцента филозофије, хладне и равнодушне жене, осветнице, која као да ишчекује пропаст свог мужа. Она доживљава радикалну промену, напушта свој калуђерски живот и везује се за човека који joj је упропастио оца. Мајка Јања, удовица, простодушна и истинољубива мајка, због своје брбљивости и искрености завршава на Голом отоку, а на крају се појављује у униформи Мао Цедунга, јединог преосталог револуционара кога није било опасно помињати. Момчило је од богатог фабриканта допао живота просјака и инвалида. Ипак, у последњем чину он се опоравља, те га на сцени видимо како аналитички и правим речима тумачи променљивост свега, дајући нам низ сентенци о животу и нацији на нашим просторима.

Социолошки аспект контраста међу ликовима Момчила и Срђе уводи нас у сукоб предратног капитализма и новог доба. Сукоб старих и искусних, с једне, и младих, пуних ентузијазма, с друге стране, резултирао је материјалним поразом искуснијих, али и душевним поразом младих. Поповић је приказао друштво детерминисаних ликова, у коме нема хероја ни антихероја, већ само ликова поражених и немоћних пред историјом. Чак и они који се у таквом свету испрва снађу или покушају да опстану на крају бивају разочарани. Сви актери постају трагикомични, сугеришући нам да се прошлост понавља деведесетих година. 
Жеље свих јунака остају неостварене, што говори о безнадежности времена представљеног у драми.

Поповић у последњем чину изводи на сцену освешћене ликове, у гротескном колу, који схватају да су сви њихови идентитети били само образине, да су потрошили животе на национализам, комунизам, сва прекомерна убеђења и заблуде.

Целокупна драма представља демитологизацију, разобличавање идеологије, била она национална, комунистичка или религијска. Поповић је истраживао проблем личног идентитета, те потрагу за сопственим местом и улогом у заједници и властитом окружењу. Писац кроз судбине својих јунака показује да зло сваке идеологије јесте прекомерност која гуши индивидуу, нарочито у народу склоном митоманији; а свака митоманија, пресвучена у идеологију, ствара хероје и антихероје који се смењују на политичкој позорници. Победника нема, сви су поражени у колу које се непрестано игра и понавља.

ЈОВА, МАЈКА ЈАњА, МОМЧИЛО И ЗОРА: (певају играјући у колу) Србин, Хрват и Словенац, савио се златан венац. Уколо, у коло, Југословенско-о-о-о.

РУЖИЦА: Нећеш. Научићу те ја како се живи с понижењем у души. А сад се спреми да изађемо. $\mathrm{V}, 3)$

СРЂА: Заслепила је мене моја острашћеност идеолошких убеђења. (Поповић 2001:

Крај драме у којој сви ликови играју у колу један је од типичних завршетака Поповићевих драма. Ту се коло не игра због разоноде, већ због симболике круга и понављања, на шта указује М. Миочиновић: „Врло је лако уочити симболичност тог враћања у круг у којем сви имају подједнака права. [...] Реч је о перманентности, типичности па дакле и репетативности ситуације коју собом доноси власт: у свету у којем нема стално привилегованих, јер сви имају подједнаке шансе, обрти у ситуацијама, или понављање исте ситуације, само са новим личностима, дакле кружност, сасвим су могућни” (Миочиновић 1975: 101).

На основу изнетих анализа, можемо закључити да сви ликови припадају Фрајевом нискомиметском модусу. Срђа има неке особине надмоћног хероја због свог политичког положаја и моћи. Међутим, Поповић није писао драму о Срђи и његовом трагичном паду, што би био природан след високомиметског модела трагичног надмоћног хероја, владара, вође, нити драму о Момчилу, који је из позиције моћи и богатства доспео у позицију антихероја. Бела кафа је у ствари драма о Ружици као трагичном хероју, док је Срђа по својим особинама и поступцима супротан Ружици. Она је у односу на све друге ликове надмоћна по свом рационалном прихватању стварности, али у исти мах охола и асоцијална. Да би спасла оца, Ружица се жртвује, а истовремено, својим трпљењем и мирноћом, и свети. Ружица чини оно што у тешким тренуцима хероје издваја од обичних људи: жртвује се ради спасавања другога. Њен лик се приближава високомиметском модусу трагичног хероја, са манама често скопчаним са херојима: охолошћу и осветољубивошћу. Момчило и Срђа изразито су сложени јунаци које можемо тумачити из различитог угла, у односу на друштвене вредности 
тог времена, као и времена у коме је драма написана. Поповић проблематизује послератну перцепцију Момчила као антихероја, издајника, па зато из угла савременог доба Момчило има особине хероја који страда због својих уверења и прошлости. Ипак, његово мучеништво није у име херојских дела, нити је последица жеље да помогне другим ликовима. Срђа је тип традиционалног хероја који не жели да трпи неправду и у то име се буни против система, друштва; он је политички ангажовани критичар режима, узор у социјалном окружењу, вођа, бунтовник, осветник. У периоду када је драма приказана обесмишљена је идеологија која би оправдавала поступке оваквих јунака. У таквим измењеним околностима, јунаци попут Срђе и остали партизански и комунистички руководиоци - нису хероји, јер су постали све оно против чега се револуција борила. „Нова област истраживања су Титови злочини (К. Николић, В. Гудач, З. Јањетовић), терор (литература о Голом отоку) и пре свега комунистичка национална политика, која је тобоже по Србе била катастрофална (В. Ђуретић, В. Крестић). Јучерашње жртве (комунисти) прерасле су у националне издајнике или совјетске агенте. И партизанска борба се тумачи у националном кључу. Историја Другог светског рата се сасвим изричито национализира и дејугославизира" (Куљић 2006: 482). Зора и Дели Јова су споредни нискомиметски комични ликови, далеко од херојског модела.

\begin{tabular}{|l|c|c|c|c|}
\hline \multicolumn{1}{|c|}{ ЛикОВи } & $\begin{array}{c}\text { Традиционални } \\
\text { херој }\end{array}$ & Нехерој & $\begin{array}{c}\text { Трагички } \\
\text { херој }\end{array}$ & Антихерој \\
\hline Ружица & & & - & \\
\hline Момчило & & + & & $(+)$ \\
\hline Срђа & $(+)$ & & & + \\
\hline
\end{tabular}

Ружица представља тип трагичког хероја из трећег модуса Фрајеве поделе. „Трагички јунак мора имати одговарајуће јуначке димензије, али његов је пад повезан и са смислом његова односа спрам друштва и са смислом надмоћности природног закона, а и једно и друго има иронијске референце” (Фрај 2000: 49). Поповић је на сцену поставио хероја који не бира између добра и зла, већ је својим унутрашњим сукобима изван друштвене реалности. Писац, дакле, стаје на страну оних хероја који нису бирали између херојства и антихеројства, оних који нису надмоћни, вође, ослободиоци, већ су преживели изван друштвене стварности у којој се перцепција херојства и антихеројства брзо смењивала.

Пошто Поповић драму Бела кафа пише 1990. године, у њој даје перцепцију савременог доба: тако је Срђа више приказан као антихерој, са негативним особинама, док је Момчило из угла савремене публике, према Фрајевој типологији, нехерој, мученик (Фрај 2000). Хероји и антихероји су само променили места, а подела на добро и зло је задржана. Ружица је као јунакиња трагичан херој, који „није нити невин нити крив”. Невин је у том смислу што је оно што се њему 
догађа кудикамо веће него што су последице ма којег његовог поступка, попут планинара чији повик изазива покретање лавине. Крив је у том смислу што је припадник друштва кривице, односно „живи у свету где су такве неправде неизбежан део егзистенције” (Фрај 2000: 55).

\begin{tabular}{|l|c|c|c|c|}
\hline \multicolumn{1}{|c|}{ ЛИкОВИ } & $\begin{array}{c}\text { Традиционални } \\
\text { херој }\end{array}$ & $\begin{array}{c}\text { Бивши } \\
\text { херој }\end{array}$ & Нехерој & $\begin{array}{c}\text { Исмејани } \\
\text { херој }\end{array}$ \\
\hline Руварац & + & & + & \\
\hline Јаша Томић & + & + & & \\
\hline $\begin{array}{l}\text { Светозар } \\
\text { Милетић }\end{array}$ & + & & & + \\
\hline $\begin{array}{l}\text { Лазар } \\
\text { Дунђерски }\end{array}$ & & & & \\
\hline $\begin{array}{l}\text { Новосаткиње } \\
\text { и остали } \\
\text { ликови }\end{array}$ & & & & \\
\hline
\end{tabular}

У анализираној драми исмејани хероји својом судбином изврћу руглу друштвену стварност. Дели Јова у Белој кафи покушава да се спасе од судбине ратовања мењајући стране, па од херојства доспева до профитерства. Срђа из Беле кафе као победник после Другог светског рата у новој идеологији је био традиционални херој, али са сумњивим особинама које нису поседовали дотадашњи модели традиционалних хероја. Драмска књижевност је деведесетих година препознала и кроз неколико ликова представила друштвени модел хероја код кога је граница између херојства и антихеројства била скоро невидљива.

\section{ЛИТЕРАТУРА}

Димић и др. 2005: Љ. Димић, Србија 1804-2004: три виђења или позив на дијалог, Београд: Библиотека Serbica.

Куљић 2006: Т. Куљић, Култура сећања: теоријска објашњења употребе прошлости, Београд: Чигоја штампа.

Ломпар 2014: М. Ломпар, Дух самопорицања, Београд: Evro-Giunti.

Симеуновић 2009: Д. Симеуновић, Увод у политичку теорију, Београд: Институт за политичке студије.

Панчић, Теофил. http://www.vreme.co.rs/cms/view.php?id=1397886. 2016. „Жив је Аца, умро није”. 13. 8. 2017. 
Поповић 2001: А. Поповић, Драме, Београд: Војноиздавачки завод.

Поповић 2001: А. Поповић, Развојни пут Боре Шнајдера и друге драме, Београд: Завод за уџбенике и наставна средства.

Фрај 2000: Н. Фрај, Анатомија критике, Загреб: Голден маркетинг.

Фрајнд 1996: М. Фрајнд, Историја у драми драма у историји, Београд - Нови Сад: Прометеј, Институт за књижевност, Стеријино позорје.

Zlatko M. Grušanović

\title{
THE TYPES OF HEROES IN SERBIAN DRAMA FROM 1990 TO 1994: ALEKSANDAR POPOVIĆ'S WHITE COFFEE
}

\begin{abstract}
Summary
The starting point for the research of this paper is the correlation of the turbulent social movements during the 1990's and the dramatic creativity throughout that decade, showed on the drama Bela kafa by Alexandar Popovic, that was very important after it was staged as a theatrical play. Research has been directed at establishing congruence in the creation and understanding of the hero as the dramatic protagonist, as well as a social phenomenon. In order to establish the concept of the hero as both a literary and social construct, the dissertation first turns towards the cultural and sociological context throughout history. This illuminates the fact that both types of heroes are nearly always the projection of the social ideal, the system of values or of social needs. It thereby shows how, throughout historical and literary eras, social ideals have shifted, the types of heroes changed, and every period in the development of society gave birth to its corresponding type of hero. As literary heroes often, but not always, personified social heroes in the world of art, it turns out that the dominant theme of this paper is, in fact, the relationship between social reality and art through the concept of heroism.
\end{abstract}

Keywords: Dramatic hero, drama, tragic hero, antihero, comic hero, grotesque, irony, satire, humor, melodrama, tragedy, comedy. 